\title{
THE EFFECTS OF CAFFEINE AND IMIDAZOLE ON THE ACTIONS OF BETA- AND ALPHA-ADRENERGIC STIMU- LANTS, PAPAVERINE AND CYCLIC 3', 5'-AMP
}

\author{
Keijiro TAKAGI, Issei TAKAYANAGI and Yukiko TSUCHIDA \\ Department of Chemical Pharmacology, Faculty of Pharmaceutical Sciences, \\ University of Tokyo, Bunkyo-ku, Tokyo, Japan \\ Received for publication November 16, 1971
}

In previous papers $(1,2)$ we have reported, using the taenia of the guinea pig, that isoprenaline, papaverine and dibutyryl cyclic AMP stop the spontaneous spike discharge with some hyperpolarization, when these relax the taenia, also that these drugs are without any effect on tension of the glycerinated taenia induced by ATP and Ca in sufficient concentrations to relax the taenia. Furthermore, we have observed that all of three drugs accelerate $\mathrm{Ca}$-efflux in the taenia (3). These results suggest that the inhibitory actions of these three drugs may be mediated through one mechanism, though only isoprenaline induces the inhibitory response via the $\beta$-adrenergic receptors.

The $\beta$-adrenergic action is thought however to be related to the ability of the $\beta$-stimulants to increase the intracellular level of cyclic 3', 5'-adenosine monophosphate (cyclic 3', 5'-AMP) in the smooth muscles. Other recent reports $(4,5)$ have mentioned that papaverine inhibits phosphodiesterase and increases the amount of cyclic 3', 5'-AMP in the cells.

One of the aims in this apper is to test whether or not inhibitory actions of the $\beta$ adrenergic stimulants and papaverine are concerned with intracellular cyclic 3', 5'-AMP as well as to determine that $\alpha$-adrenergicacti on is not related to cyclic $3^{\prime}, 5^{\prime}$-AMP in the cells.

\section{METHODS}

After sacrificing a male guinea pig ( 300 to $400 \mathrm{~g}$ in body wt) by a blow on the neck, the taenia was isolated from the caecum. A piece $(4$ to $5 \mathrm{~cm})$ of the taenia was suspended in the $30 \mathrm{ml}$ organ bath filled with Locke Ringer solution, kept at $37 \mathrm{C}$ and bubbled with air. Responses of taenia to drugs were isotonically recorded. Locke Ringer solution used had the following composition : $9.0 \mathrm{~g}$ of $\mathrm{NaCl}, 0.4 \mathrm{~g}$ of $\mathrm{KCl}, 0.2 \mathrm{~g}$ of $\mathrm{CaCl}_{2}, 0.2 \mathrm{~g}$ of $\mathrm{MgCl}, 0.5 \mathrm{~g}$ of $\mathrm{NaHCO}_{3}$ and $0.5 \mathrm{~g}$ of glucose in a litre. Concentration action curve was cumulatively obtained $(6,7)$. The results in this paper are expressed as means of at least 10 experiments.

Drugs used: adrenaline hydrochloride (adrenaline), cyclic 3', 5'-adenosine monophosphate (cyclic 3', 5'-AMP), l-isoprenaline hydrochloride (isoprenaline), papaverine hydro-

This work was partly supported by a research grant (No. 57005) from the Ministry of Education, Japan. 
chloride (papaverine), phenylephrine hydrochloride (phenylephrinc), caffeine Na-benzoate (caffeine) and imidazole hydrochloride (imidazole). Abbreviations in the parenthesis are used in this paper. Concentrations of drugs are expressed as final concentrations $(\mathrm{g} / \mathrm{ml})$ of the salts in the bath.

\section{RESULTS}

Effects of dibenamine, $\alpha$-adrenergic blocker and propranolol, $\beta$-adrenergic blocker on the inhibitory responses to isoprchaline, adrenaline, phenylephrine and papaverine

Propranolol $\left(10^{-6} \mathrm{~g} / \mathrm{ml}\right)$ greatly antagonized the inhibitory response to isoprenaline, so that the concentration action curve of isoprenaline shifted towards a 10 times higher con-
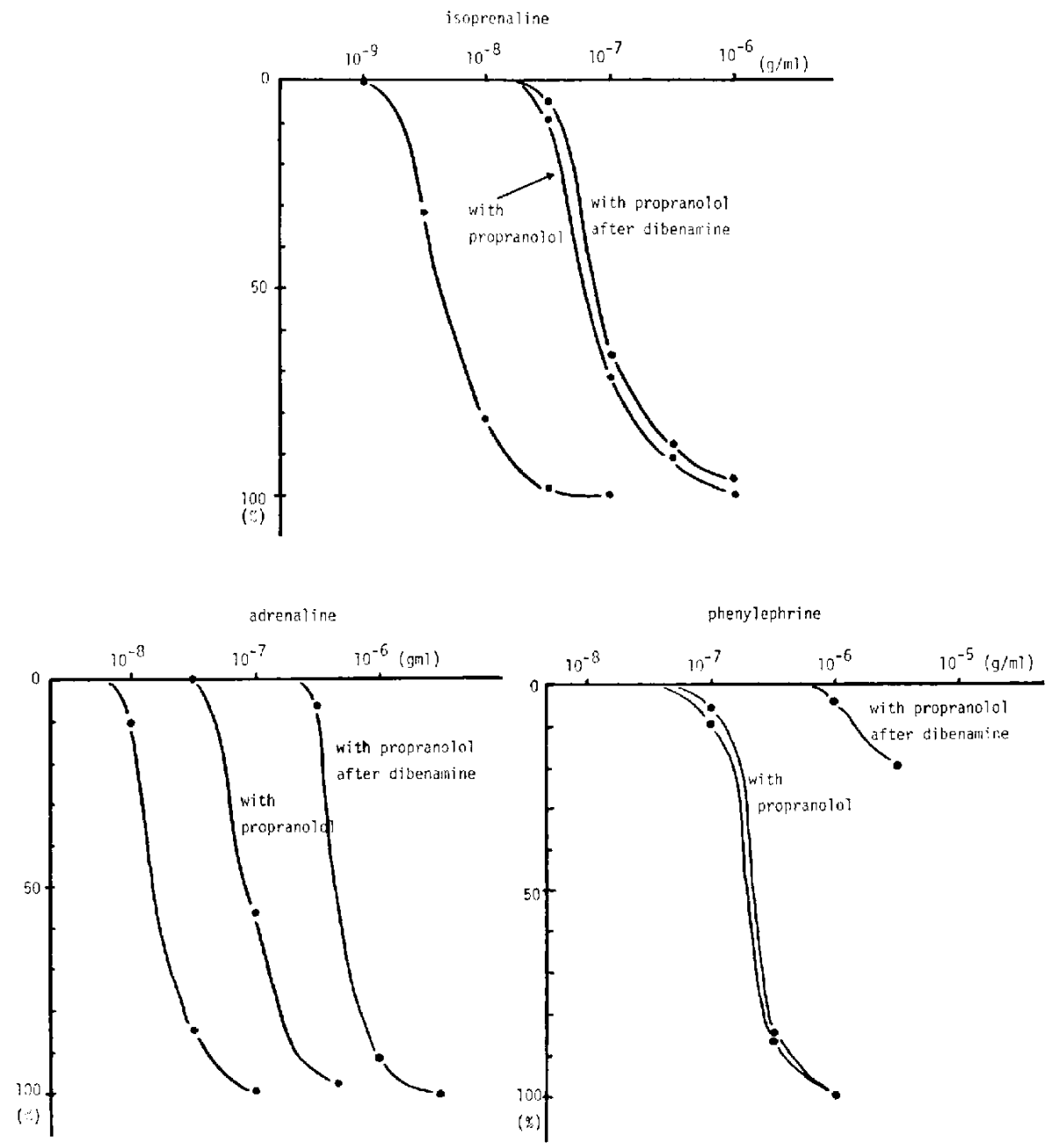

FIG. 1. Effects of propranolol $\left(10^{-6} \mathrm{~g} / \mathrm{ml}\right)$ and of both dibenamine $\left(10^{-6} \mathrm{~g} / \mathrm{ml}\right)$ and propranolol $\left(10^{-6} \mathrm{~g} / \mathrm{ml}\right)$ on inhibitory responses to isoprenaline, adrenaline and phenylephrine.

Antagonisms between propranolol and the adrenomimetics werc first tested, followed by the effects of dibenamine on the residual responses in the presence of propranolol. 
centration in the presence of propranolol $\left(10^{-6} \mathrm{~g} / \mathrm{ml}\right)$. On the other hand, the concentration action curve of adrenaline shifted to only a 6 times higher concentration. The inhibitory responses to phenylephrine and papaverine were however little affected by propranolol $\left(10^{-6} \mathrm{~g} / \mathrm{ml}\right)$. The residual responses to adrenaline and to phenylephrine in the presence of propranolol $\left(10^{-6} \mathrm{~g} / \mathrm{ml}\right)$ were greatly reduced by the $10 \mathrm{~min}$ incubation of the taenia with dibenamine $\left(10^{-6} \mathrm{~g} / \mathrm{ml}\right)$. These are shown in Fig. 1.

The following experiments were down on new strips. Ten min incubation of the tania with dibenamine $\left(10^{-6} \mathrm{~g} / \mathrm{ml}\right)$ abolished the inhibitory response to phenylephrine and shifted somewhat the concentration action curve of adrenaline. The inhibitory responses to isoprenaline and 10 papaverine were little alfected by dibenamine $\left(10^{-6} \mathrm{~g} / \mathrm{ml}\right)$. The
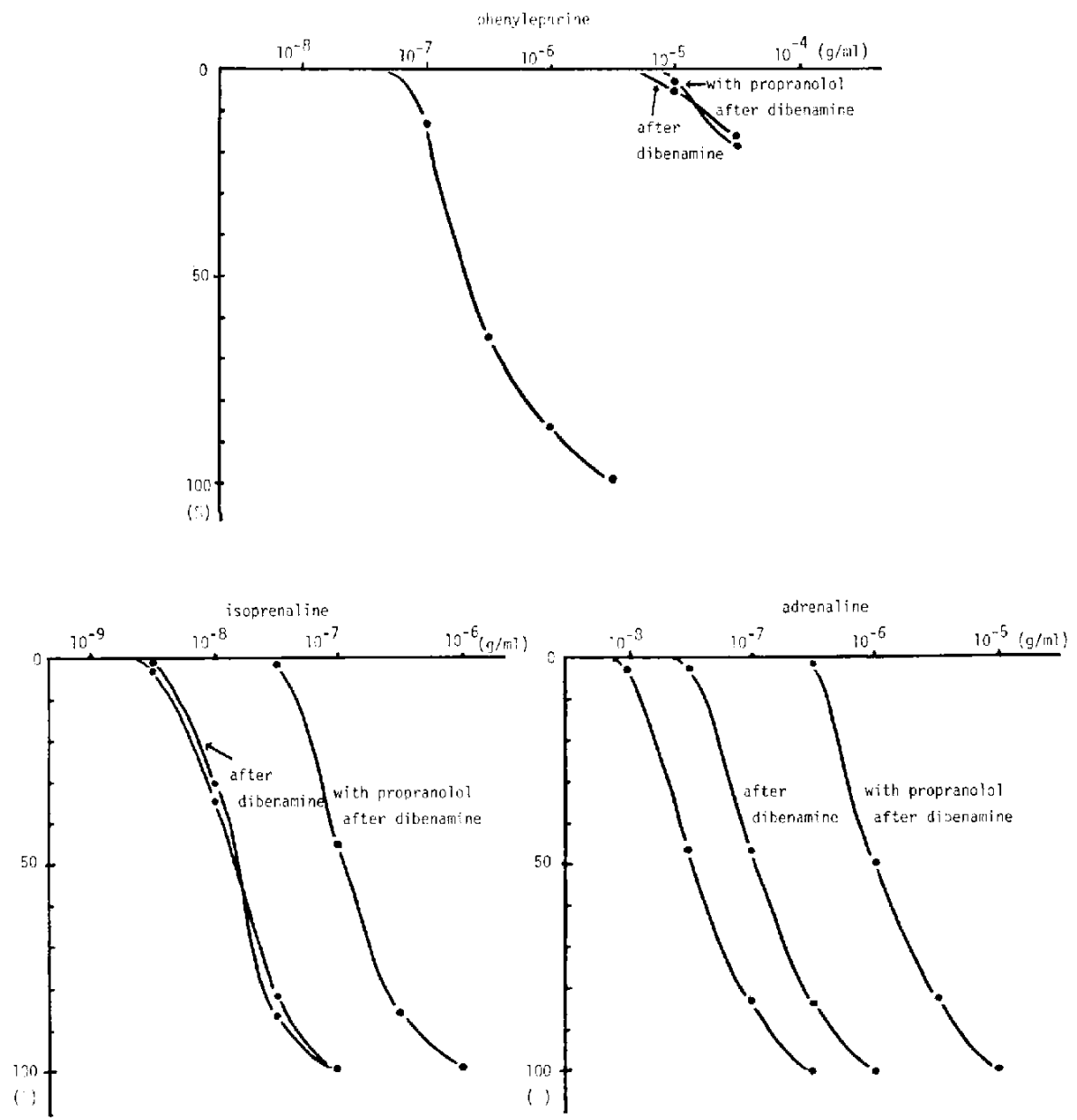

FIG. 2. Effects of dibenamine $\left(10^{-\hat{f}} \mathrm{~g} / \mathrm{ml}\right)$ and of both dibenamine $\left(10^{-6} \mathrm{~g} / \mathrm{ml}\right)$ and propranolol $\left(10^{-c} \mathrm{~g} / \mathrm{ml}\right)$ on the inhibitory responses to phenylephrine, adrenaline and isoprenaline.

The effect of dibenamine $\left(10^{-6} \mathrm{~g} / \mathrm{ml}\right)$ on the inhibitory responses to the adrenomimetics was first tested, after which antagonisms between propranolol and them were examined using the same preparations. 
residual responses to adrenaline and to isoprenaline after the 10 min incubation with dibenamine were greatly reduced by propranolol $\left(10^{-6} \mathrm{~g} / \mathrm{ml}\right)$. The above mentioned phenomena is shown in Fig. 2. This indicates that isoprenaline induced only $\beta$-adrenagic action. Phenylephrine also demostrated only $\alpha$-adrenergic action with adrenaline having both $\alpha$-and $\beta$-adrenergic actions in the concentrations used here.

Effects of caffeine, an agent that inhibits phosphodiesterase inhibitor on the inhibitory responses of the taenia to isoprenaline, cyclic 3', 5'-AMP, adrenaline, phenylephrine and papaverine After concentration action curves of isoprenaline, cyclic 3',5'AMP, adrenaline,
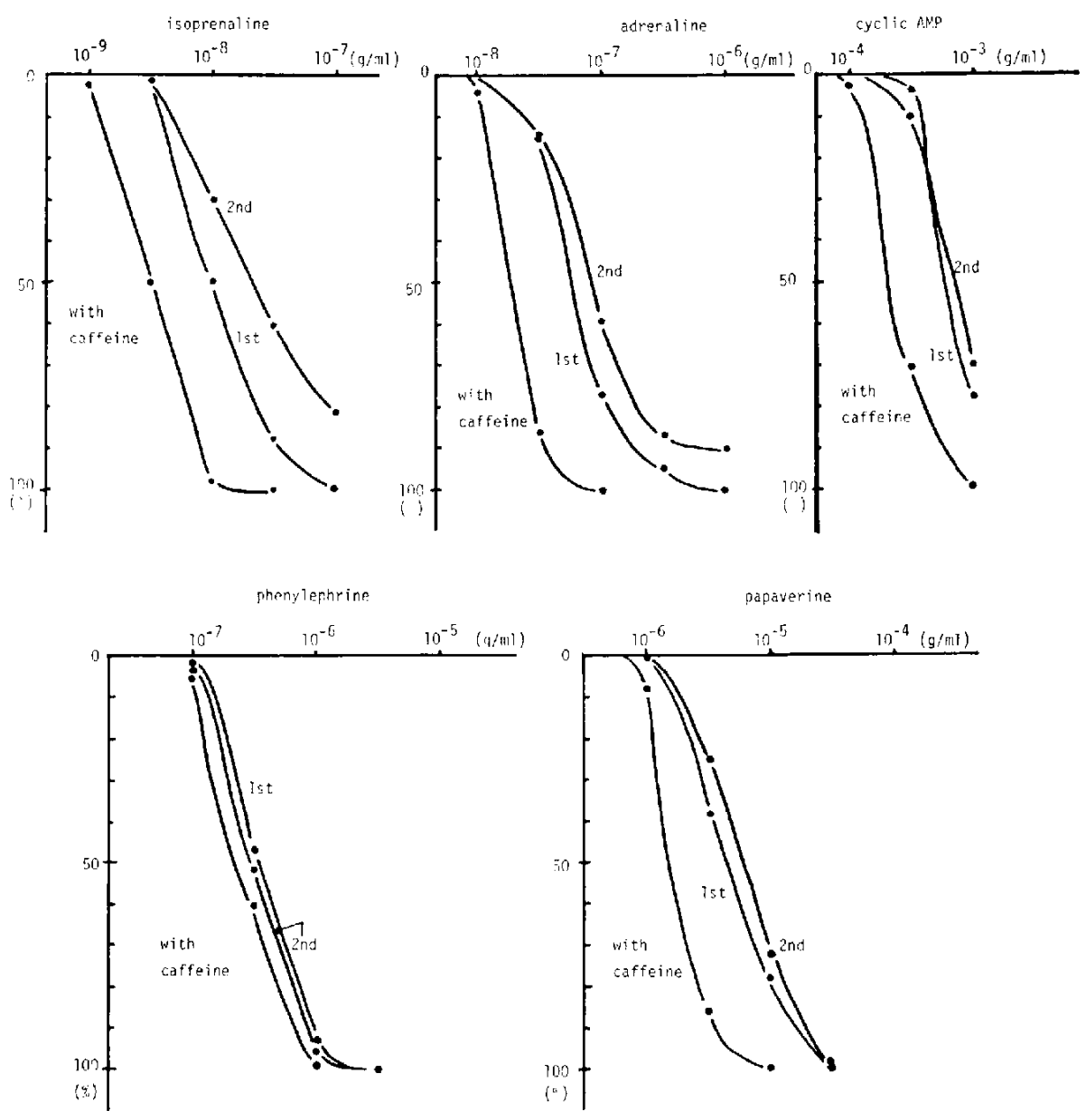

Fig. 3. Effect of caffeine $\left(10^{-4} \mathrm{~g} / \mathrm{ml}\right)$ on the inhibitory responses to isoprenaline, adrenaline, cyclic $3^{\prime}, 5^{\prime}$-AMP, papaverine and phenylephrine.

$1 \mathrm{st}$ : responses obtained before treatment with caffeine

2 nd : responses obtained after experiments with caffeine were carried out and the taenia was washed ih bath fluid for $1 \mathrm{hr}$.

$100 \%=$ the maximum response to isoprenaline.

Note that caffeine potentiated the responses to isoprenaline, adrenaline, cyclic $3^{\prime}, 5^{\prime}$-AMP and papaverine. 

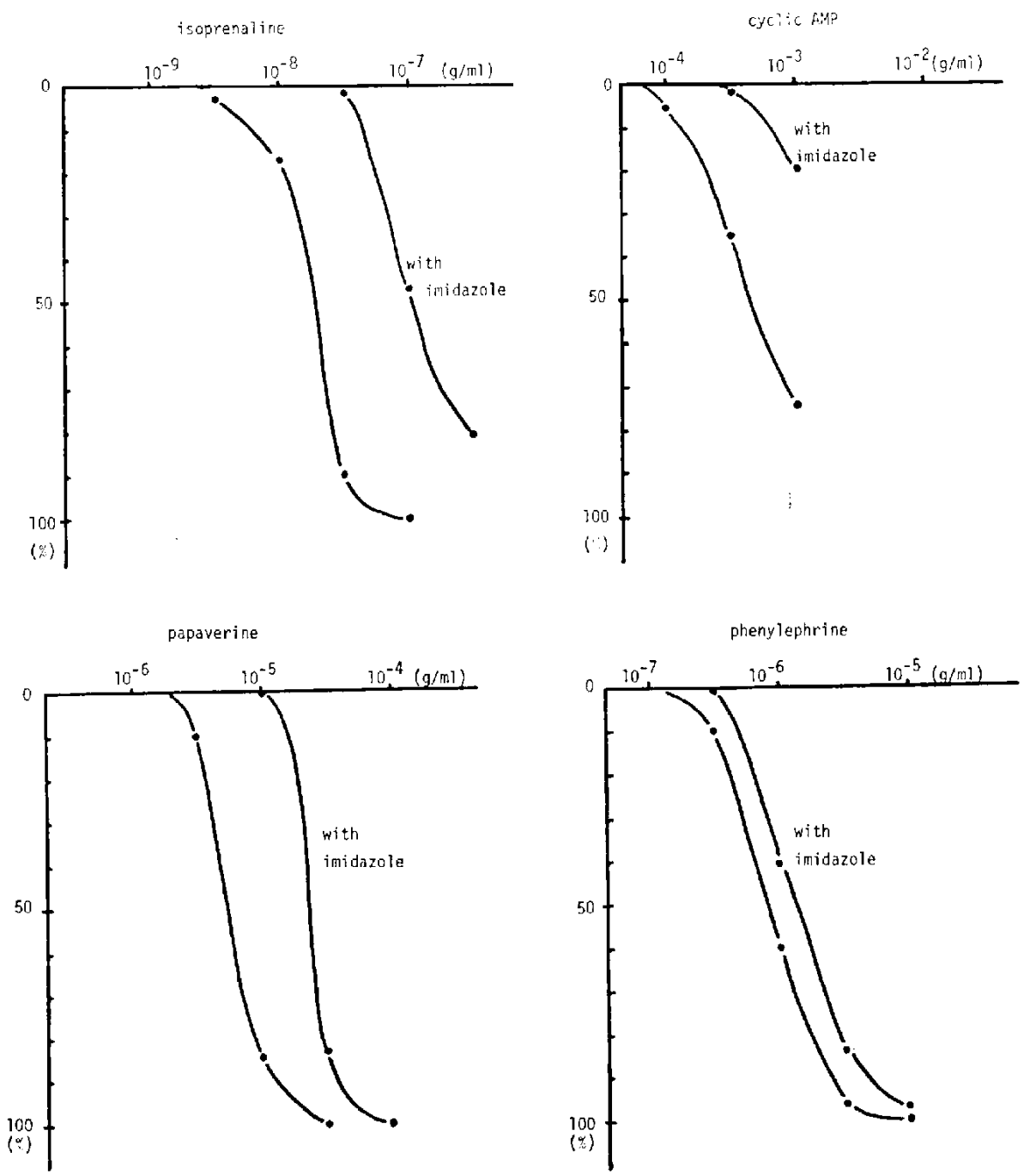

FIG. 4. Effects of innidazole $\left(10^{-4} \mathrm{~g} / \mathrm{ml}\right)$ on the inhibitory responses to isoprenaline, cyclic $3^{\prime}, 5^{\prime}$-AMP, papaverine and phenylephrine.

$100 \%=$ the maximum response to isoprenaline.

Note that imidazole reduced the inhibitory responses to isoprenaline, cyclic 3', 5'-AMP and papaverine.

phenylephrine and papaverine were obtained as control responses, caffeine $\left(10^{-4} \mathrm{~g} / \mathrm{ml}\right)$ was added to the bath fiuid. The taenia was immediately relaxed by caffeine recovered to the original within $15 \mathrm{~min}$. After that, the concentration action curves were again obtained in the presence of caffeine. The inhibitory responses to isoprenaline, cyclic 3', 5'-AMP, adrenaline and papaverine were potentiated as shown in Fig. 3. Phenylephrine was however slightly potentiated by caffeine $\left(10^{-4} \mathrm{~g} / \mathrm{ml}\right)$. 
Effects of imidazole, an agent that increases phosphodiesterase, on the inhibitory responses of the taenia to isoprenaline, cyclic $3 *, 5 *-A M P$, phenylephine and papaverine

After the concentration action curves of isoprenaline, cyclic 3', 5'-AMP, phenylephrine and papaverine were obtained, the taenia was treated with imidazole $\left(10^{-4} \mathrm{~g} / \mathrm{ml}\right)$ for $20 \mathrm{~min}$. The concentration action curves were again obtained in the presence of imidazol $\left(10^{-4} \mathrm{~g} / \mathrm{ml}\right)$. The responses of the taenia to isoprenaline, cyclic $3^{\circ}, 5^{\prime}$-AMP and papaverine were reduced by imidazole, while phenylephrine was slightly inhibited. These are shown in Fig. 4.

Antagonism between caffeine and imidazole on the inhibitory response to isoprenaline and papaverine

After it was confirmed that the inhibitory responses to isoprenaline and papaverine were potentiated by caffeine $\left(10^{-4} \mathrm{~g} / \mathrm{mI}\right)$, the inhibitory responses to isoprenaline and papaverine were again obtained in the presence of both caffeine $\left(10^{-4} \mathrm{~g} / \mathrm{ml}\right)$ and imidazole $\left(10^{-4} \mathrm{~g} / \mathrm{ml}\right)$. The responses to isoprenaline and papaverine, which were potentiated by caffeine $\left(10^{-4} \mathrm{~g} / \mathrm{ml}\right)$, were greatly reduced by application of both caffeine $\left(10^{-4} \mathrm{~g} / \mathrm{ml}\right)$ and imidazole $\left(10^{-4} \mathrm{~g} / \mathrm{ml}\right)$ (Fig. 5).

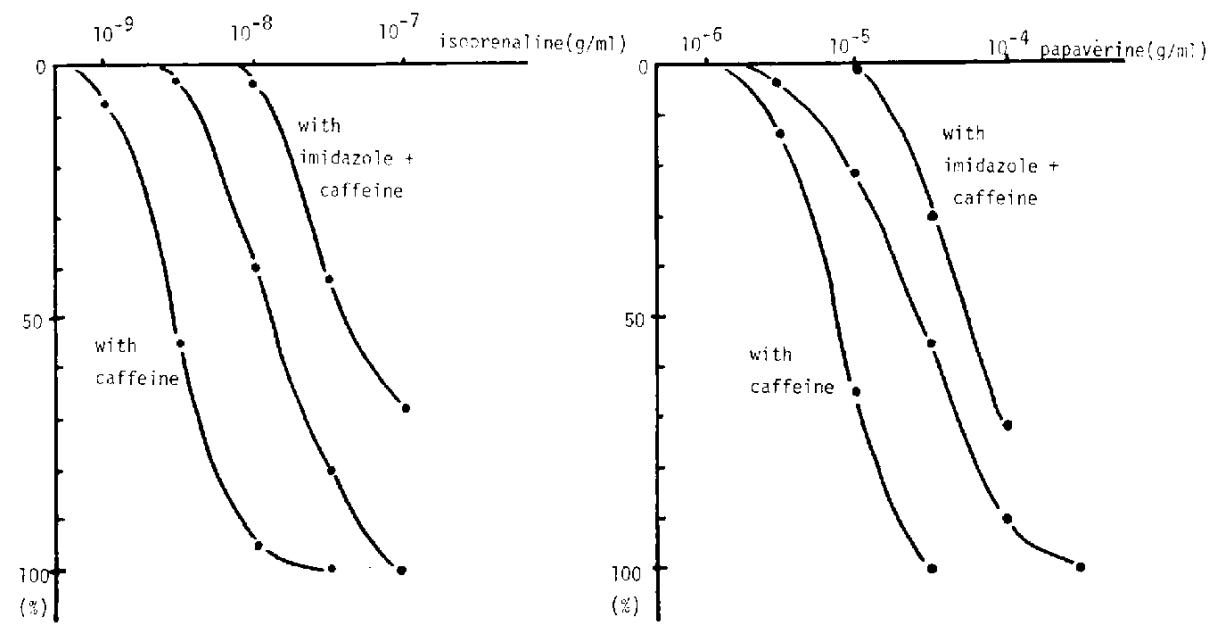

FiG. 5. Antagonism between caffeine $\left(10^{-4} \mathrm{~g} / \mathrm{ml}\right)$ and imidazole $\left(10^{-4} \mathrm{~g} / \mathrm{ml}\right)$ on the responses to isoprenaline and papaverine.

\section{DISCUSSION}

It can be ascertained from the above mentioned results (Figs. 1 and 2) that the inhibitory response to isolprenaline is mediated through pure $\beta$-adrenergic action and that to phenylephrine through pure $\alpha$-adrenergic action. Caffeine, an agent that inhibits phosphodiesterase (8), potentiated the inhibitory responses to isoprenaline (9), cyclic 3', 5'AMP and papaverine. Inidazole, an agent that increases phosphodicsterase activity (8), decreases the responses of the tacnia to isoprenaline, cyclic 3', 5'-AMP and papaverine. Antagonistic relation between caffeine and imidazole on the inhibitory responses was 
also observed. Neither agents influenced the inhibitory response to phenylephrine, an $\alpha$ adrenergic stimulant (8). These results indicate the possibility that the actions of $\beta$ adrenergic stimulants and papaverine are mediated through increase of the intracellular level of cyclic 3',5'-AMP and that cyclic 3', 5'-AMP is not related to the responses to $\alpha$-adrenergic stimulants.

If the modifications of the inhibitory responses to isoprenaline and papaverine by caffeine and imidazole are attributed to their non specific actions, they might also be expected to modify the response to phenylephrine. Such phenomena were not observed. If caffeine and imidazole influence only phosphodiesterase activity in the guinea pig taenia in a manner similar to that observed in enzyme preparations, the ability of both drugs to influence the inhibitory responses to the $\beta$-adrenergic stimulants and papaverine may be explained on the basis of a change of the intracellular level of cyclic 3', 5'-AMP. Even if the above assumption is correct, the problem still remains unknown whether or not the role of intracellular 3, 5'-AMP in the $\beta$-adrenomimetic action is the quite same as that of cyclic 3', 5'-AMP in the action of papaverine.

\section{SUMMARY}

Caffeine that inhibits phosphodicsterase potentiated the inhibitory responses of the guinea pig taenia to isoprenaline, cyclic 3', 5'-AMP and papaverine. Imidazole that increases phosphodiesterase activity decreases the inhibitory response of the same tissue. On the other hand, the action of phenylephrine was little influenced by caffeine or imidazole. These results support the hypothesis that cyclic 3', 5'-AMP is a mediator in the inhibitory responses to $\beta$-adrenomimetics and papaverine and indicate that the action of $\alpha$-adrenomimetics is not concerned with the intracellular cyclic 3 ', 5-AMP.

\section{REFERENCES}

1) Takagi, K., Takayanagi, I. And Tomiyama, A.: Jap. J. Pharmac, 21, 271 (1971)

2) Takagi, K., Takayanagi, I. and Tomiyama, A.: Jap. J. Pharmac. 21, 477 (1971)

3) Takagi, K., Takaynnagi, I. And Tomiyama, A.: Abstracts of Amual Meeting of Pharmaceutical Society of Japan, 71-4-1 (1971)

4) Triner, L., Vulliemoz, Y., Scilwartz, I. and Nailas, G.G.: Biochem. biophys. Res. Commum. 40, 64 (1970)

5) Pöch, G. and Kukovetz, W.R.: Life Sci. 10, 133 (1971)

6) Van Rossum, J.M.: Archs int. Pharmacodyn. Therr. 143, 299 (1963)

7) Takayanagi, 1.: Pharmacometrics 2, 131 (1969)

8) Butcher, R.W. AND Sutherland, E.W.: J. biol. Chem. 237, 1244 (1962)

9) Wilkenfeld, B.E. And Levy, B.: $J$. Pharmac. exp. Ther. 169, 61 (1969) 